ILGAR MAMEDOV, Candidate of Historical Sciences, Senior Research Fellow Institute of Slavic Studies, Russian Academy of Sciences

Moscow, Russian Federation

ilgarmm@yandex.com

originalan naučni rad

UDK: 327(560:497)"199/..."

primljeno: 5. oktobar 2019.

prihvaćeno: 20. novembar 2019.

https://doi.org/10.29362/ist20veka.2020.1.mam.185-202

\title{
THE BALKAN POLICY OF TURKEY IN CONNECTION WITH THE KOSOVO CRISIS IN 1998-1999
}

\begin{abstract}
Turkey's involvement in the bombing of Yugoslavia in 1999 was caused by the need to reinforce Turkey's influence in the Western community, safeguard its regional interests, and support the election campaign. Turkey tried to correlate its policy with that of the West. However, the fundamental interests of Turkey and the West did not coincide. This was "Turkey's Balkan Dilemma".
\end{abstract}

KEYWORDS: Aggression, Albania, Balkans, Turkey's Balkan Dilemma, Bombing, Kosovo, NATO, Turkey, Yugoslavia

Several permanent factors determined Turkey's interests in the Balkans. A number of circumstances influenced its policy in the 1990s.

\section{The Importance of the Balkans to Turkey}

The Ministry of Foreign Affairs of Turkey states that the Balkans is a priority, not only from the political, economic, and geographic perspectives, but also due to its historical, cultural, and human ties with the region. The Balkans provides a geographical connection between Turkey and the rest of Europe. The peninsula bears great importance with the special place it had in the historical process that shaped the Turkish nation. ${ }^{1}$ In addition, a small part of Turkey is located on the Balkan Peninsula, and it is itself a Balkan country.

The Balkans is a home for Turkish minorities and kin communities. Persons of Balkan origin live in Turkey as well. By some estimates, there are around 10 million Turks of Balkan origin and from 4 to 10 million people from the Balkan countries residing in Turkey. ${ }^{2}$ According to Turkstat statistics, about

\footnotetext{
${ }^{1}$ Relations with the Balkan Region // Ministry of Foreign Affairs of the Republic of Turkey. Foreign Policy. Regions. Balkans. http://www.mfa.gov.tr/relations-with-the-balkan-region.en.mfa (accessed: 03.02.2019 г.).

${ }^{2}$ Marija,Mitrovic. 2014: Turkish Foreign Policy toward the Balkans: The influence of traditional determinants on Davutoğlu's conception of Turkey - Balkan relations. GeT MA Working Paper
} 
1 million Turks live in the Balkans, about 16 to 20 million Turkish residents have Balkan roots. ${ }^{3}$ Around 11 million Muslims are spread unevenly throughout the Balkan countries, most notably in Bulgaria, Albania, the former Yugoslavia, and northern Greece. ${ }^{4}$ Turks have traditionally been one of the most numerous nationalities in the Socialist Federal Republic of Yugoslavia (SFRY), where historically they have been concentrated in Macedonia and Kosovo. On the eve of the breakup of Yugoslavia, the total number of Turks was about 150,000. ${ }^{5}$ Muslims living in the Balkan countries actively sought protection and support from Turkey, hoping with its help to resolve the problems of their nationalcultural or political self-determination. However, Turkey, according to Paniyev, took a cautious stance in this matter and did not give grounds for accusations of using the Muslim population for promoting its own interests. ${ }^{6}$

\section{Lobbying of Turkish Albanians}

In connection with the exacerbation of the Kosovo crisis, associations representing the Albanian community lobbied quite actively for Kosovo, organized meetings with Turkish deputies and officials, and distributed their messages to the press. The inauguration of the representative office of the Republic of Kosovo in Istanbul was held in December of 1996. The opening ceremony was attended by the Albanian ambassador to Turkey, the information minister of the Republic of Kosovo, and the vice-president of the Democratic League of Kosovo. ${ }^{7}$ Albanian associations organized two demonstrations in Istanbul, one on 8 March of 1998 and the other two months later.

Despite the active mobilization of its "leaders", the Albanian community itself did not really take part in this lobbying. These Albanians are in fact generally "turkified" and most of them do not even speak Albanian anymore. They definitely were concerned about the fate of their compatriots in Kosovo. Money collected by Albanian associations for humanitarian purposes in the spring of 1999 was rather meager. The Turkish Albanians did not join the Kosovo Liberation Army (KLA). However, in the spring of 1999, they assisted the refugees by placing some of them in their homes or by preparing a country house near the camp of Kirklareli in Thrace for their accommodation. The Turkish Government did not

no. 10. Department of Social Sciences, Humboldt-Universität zu Berlin. [online] Homepage: Edoc Server Humboldt-Universität zu Berlin. URL: http://edoc.hu-berlin.de/series/getmaseries 49.

${ }^{3}$ Adriano Remiddi, "Tureckoe vtorzhenie na Zapadnye Balkany: perspektiva evroatlanticheskogo primirenija", u: Jugo-Vostochnaja Evropa: mezhdu proshlym i budushhim. Doklady Instituta Evropy, № 290 (M.: Institut Evropy RAN: Rus. suvenir, 2013), 78.

${ }^{4}$ Kemal H. Karpat, "Turkish Foreign Policy: Some Introductory Remarks", in: Turkish Foreign Policy: Recent Developments. Kemal H. Karpat (eds.) (Madison: Wisconsin, 1996), 4.

5 Şule Kut, "Turks of Kosovo: What to Expect?", Perceptions, vol. V, no. 3. (SeptemberNovember 2000).

${ }^{6}$ G. Paniev, "Sovremennaja politika Turcii na Balkanah", u: Vestnik Pjatigorskogo gosudarstvennogo lingvisticheskogo universiteta. Molodezhnoe prilozhenie. № 1. (Pjatigorsk, 2002), 106-107.

${ }^{7}$ Sylvie Gangloff, "Turkish policy toward the conflict in Kosovo: the preeminence of national political interest”, Balkanogie, vol. 8, no. 1 (2004), 115-116. 
support the initiatives of these associations and did not authorize the two demonstrations organized in the spring of 1998, nor did the opening of the mission of the Republic of Kosovo in Istanbul receive any official support. No government officials attended the event. On March 8, 1998, the police blocked the way to the Yugoslav Consulate, where the demonstrators were heading. ${ }^{8}$

\section{The Kosovo Turks}

The Turkish minority numbered around 12,000 persons according to the 1991 census ( $0.6 \%$ of the total population of the province of Kosovo), but the Kosovo Turks claimed that their number was at least 60,000. This figure is also widely quoted in official and unofficial Turkish sources. They claimed that the 1991 census was not reliable due to political manipulation and that the number of Turkish speakers was even much larger. ${ }^{9}$

Despite their constitutional rights, the years of 1974-1989 were a difficult period for the Turks of Kosovo. The Albanian authorities pursued a policy of Albanization of Kosovo, if not an anti-Turkish policy as such. As a result, many Turks were forced to either be assimilated or change their ethnic identity. Albanian nationalism was and remains one of the strongest in the Balkans. Although nationalism makes no distinction between different "others", Turks in particular were especially "others" to Albanians with whom they share the same religion and culture. Moreover, the Albanians denied the very existence of the Turkish ethnic group in Kosovo. ${ }^{10}$

Belgrade's attitude toward the Turks was very different from that of the Albanians. Belgrade granted many cultural rights to the Turks in the 1960s and '70s. After the 1968 revolt in the province, Belgrade supported the publication of several newspapers in Turkish and Turkish was listed as an official language in the 1974 Constitution. In 1985, a department of Turkish studies was opened at the University of Pristina. In the mid-1990s, this department registered around 50 students. ${ }^{11}$

\section{Noninterference Policy}

Turkey opposed the break-up of Yugoslavia, fearing instability, and did not recognize the independence of Slovenia and Croatia. In January of 1991, initially the Vatican, then Germany, the rest of the EU countries, and the United States, recognized the independence of these two former Yugoslav republics and only then did Turkey follow suit.

Turkey has pursued a very cautious and passive policy. It preferred to act only in accordance with the West, avoided unilateral actions, and did not take sides. During the Bosnian war, Turkey called for NATO intervention to

\footnotetext{
${ }^{8}$ S. Gangloff, "Turkish policy toward the conflict in Kosovo...", 115-116.

${ }^{9}$ Ibid., 117.

${ }^{10}$ Ş. Kut, op. cit.

${ }^{11}$ S. Ganglof, "Turkish policy toward the conflict in Kosovo...", 117.
} 
end the bloodshed. Some Turkish civic initiatives provided financial assistance to Bosnians. During the war in 1994, Turkey helped broker an alliance between the Croats and the Bosniaks against the Serbian offensive by offering to build Zagreb-Rijeka highway in partnership with the joint consortium of the Turkish ENKA and the American Bechtel. ${ }^{12}$

By basing its Balkan policy on the norms and principles of international law, Ankara ensured its legitimacy. It openly refused to participate in military interventions. Turkey has been particularly cautious with regard to the Federal Republic of Yugoslavia (FRY). After the collapse of the SFRY and the beginning of conflicts, Turkish leaders tried not to antagonize the FRY. For example, they waited four months, until May of 1992, before recalling their ambassador after Belgrade recalled its envoy in January 1992. When NATO issued an ultimatum to Serbia in February of 1994, Turkey certainly backed this but proposed its participation in air strikes only for logistic missions. At the same time, despite the UN embargo, Turkey decided to support the Bosnian Muslims with weapons. It was, perhaps, the only case when Turkey acted independently. Again, in August of 1995, during Operation Deliberate Force, Turkey welcomed the action but the Turkish Air Force did not participate in the actual bombing. ${ }^{13}$

Turkey participated in the implementation of the Dayton agreements. On 4 January 1997, the Turkish frigates "Adatepe" and "Orucreis" sailed from the base Gölcük (Izmit) to participate in the activities of the NATO forces for the implementation of the Dayton and Paris agreements. ${ }^{14}$ After the Dayton agreement, Turkish leaders quickly resumed relations with the Serbs.

Turkey has also worked hand in hand with Washington in the planning of its regional diplomacy. It was only after the United States got involved in the settlement of the conflict in Bosnia-Herzegovina in 1994-1995 and after it recognized the FYROM and signed military agreements with the latter, that Turkey itself took the step of signing military agreements with Macedonia in April of 1995 and July of 1996, and Bosnia-Herzegovina in August of 1995 and January of 1996. Again, in the spring of 1998, only after the deepening of the military cooperation between Macedonia and NATO, Turkey, also strengthened its own military cooperation with Skopje. Like the United States, Turkey supported Albania, Macedonia, and the Bosnian-Croat Federation politically and militarily. Lastly, Washington and Ankara undertook a collaborative effort to rearm and train the Croat-Muslim army in the framework of the US "Train and Equip Program". 15

\footnotetext{
12 Doğa Ulaş Eralp, "Turkey and Bosnia-Herzegovina: A Future Reflecting on the Past", SETA. Policy Brief. no. 46, (August 2010), 4.

${ }^{13}$ S. Gangloff, "Turkish policy toward the conflict in Kosovo...", 107.

${ }^{14}$ Arhiv vneshnej politiki Rossijskoj Federacii (AVP RF). Fond (F). 194. Opis (Op). 77. Papka (P). 238. Delo (D). 6. List (L). 2.

${ }^{15}$ S. Gangloff, "Turkish policy toward the conflict in Kosovo...", 107.
} 


\section{The Kosovo Dilemma}

In the mid-1990s, the KLA began to operate in Kosovo and announced on February 28, 1998 the beginning of the armed struggle for the independence of the province. Through covert channels, mainly operated by the CIA, in the period from late 1998 to early 1999, weapons and funds were transferred to supply the KLA. CIA agents later reported that they entered Kosovo in 19981999 as OSCE observers responsible for verifying the ceasefire, provided US military training manuals and satellite phones to the militants so that their commanders could communicate with NATO and Washington. In response, Belgrade deployed its police and armed forces in Kosovo and Metohija. In JulyAugust 1998, the Serbian armed forces managed to eliminate the main strongholds of the KLA, which controlled up to $40 \%$ of the territory of the province.

Even before the outbreak of the crisis in the spring of 1998, Turkish leaders were extremely cautious in their Kosovo policy. The Kosovars had been urging them to help. As early as 1992, Ibrahim Rugova travelled to Turkey and asked for recognition. Bujar Bukoshi, the prime minister of the "shadow cabinet", asked Turkey to send observers to the 22 March 1998 elections. Adem Demaqi, Kosovar Albanian writer and politician, called on Turkey to be more active in settling the problem of Kosovo. In response to Ankara's silence, most of the Kosovo leaders expressed their disappointment with this "passive policy".

When armed clashes broke out in Kosovo in 1998, as was the case in the war in Bosnia-Herzegovina, Turkey condemned the violence in Kosovo, called for constructive dialogue, and offered its participation in the international peacekeeping forces. However, unlike its reaction to the events in Bosnia-Herzegovina, it showed no practical activity other than diplomatic. Turkey was facing a dilemma. Bosnia-Herzegovina was a federal republic of the SFRY and after the breakup of Yugoslavia its independence was recognized internationally. But Kosovo, unlike Bosnia-Herzegovina, was not a federal republic; it was an autonomous province within Serbia, another federal republic. After the breakup of Yugoslavia, it was part of the FRY, whose territorial integrity was recognized by the international community. Turkey did not support Kosovo separatism, especially since it fought a similar separatism on its own territory. Many have drawn attention to this analogy between Kosovo and Kurdistan. The Yugoslav ambassador in Ankara, for example, did not miss an opportunity to refer to the fight against the PKK in Turkey, stating, "Turkey should understand Belgrade better than any other country since it is involved in a similar situation". ${ }^{16}$

Throughout 1998, the Yilmaz government remained in fact extremely indifferent to developments in Kosovo, especially during the Serbian military operations in the summer. ${ }^{17}$ Turkey only tried to maintain a dialogue. After the

\footnotetext{
${ }^{16}$ S. Gangloff, "Turkish policy toward the conflict in Kosovo...", 109.

${ }^{17}$ Ilhan Uzgel, "Kosovo; Politics of Nationalism and the Question of International Intervention", Turkish Review of Balkan Studies, 4, (1998-1999), 330.
} 
beginning of the crisis in Kosovo on 7-8 March 1998 Ismail Cem, the Turkish foreign minister visited Belgrade and held talks with FRY President Slobodan Milošević and Foreign Minister Jovanović. ${ }^{18}$ A meeting of military representatives of Turkey, the USA, Bulgaria, Macedonia, Romania, Albania, and Slovenia took place in Ankara on March 16-18, 1998. On the agenda was the issue of establishing multinational peacekeeping forces in the Balkans. Turkish Foreign Minister Cem took part at the Bonn meeting of the Contact Group on the settlement of the situation in Kosovo on 25 March $1998 .{ }^{19}$ On July 10, 1998, the Turkish Ambassador to the FRY, A. Kıliç conveyed to the leader of Kosovo Albanians, I. Rugova in Pristina an official invitation from Foreign Minister Cem to visit Turkey. ${ }^{20}$

Turkey has also offered peace initiatives. In his speech in the Albanian Parliament, President Demirel, who was in Tirana on 14-15 July 1998 at the invitation of Albanian President R. Meidani, called on the world community to jointly stop the Serbian aggression in Kosovo and bring the warring parties to the negotiating table immediately. ${ }^{21}$ On July 23, 1998, the Turkish Parliament authorized the Council of Ministers to send a military contingent to Albania if such a need arose due to the worsening situation in Kosovo. ${ }^{22}$ On 27 July 1998, S. Demirel sent a letter to the leaders of the Contact Group and to FRY President S. Milošević urging them to seek a peaceful settlement of the conflict between Belgrade and the Albanian separatists in Kosovo. ${ }^{23}$ On October 8, 1998, the deputies of the Grand National Assembly of Turkey unanimously voted in favor of granting powers to the government to authorize the participation of the Turkish Armed forces in possible NATO peacekeeping operations in Kosovo. ${ }^{24}$

Ankara's main concern was the fear of repressions against the local Turks by the Albanians, the risk of spreading the Kosovo conflict to the entire peninsula. The most common scenario in Turkey was the fear that if the Albanians in Kosovo gained independence, Albanians in Macedonia would follow the movement, provoking a break-up of the Republic of Macedonia and intensifying the regional conflict. Turkey immediately increased its military assistance to Macedonia, where there was a large Albanian community closely linked with the Kosovo Albanians. In June of 1998, negotiations were underway to supply the Macedonian army with 20 F-5 fighter planes and train Macedonian pilots in Turkey. Turkish leaders remained committed to preserving the territorial integrity of the FRY and were extremely cautious about interfering in Kosovo's internal affairs.

Without taking any practical action, the Turkish leaders continued formally to advocate the "restoration" of the rights of all ethnic groups in Kosovo. Turkey showed an understanding for Albania's position in connection with the

\footnotetext{
${ }^{18}$ AVP RF. F. 194. Op. 78. P. 241. D. 6. L. 35.

${ }^{19}$ Ibid. L. 36.

${ }^{20}$ Ibid. L. 45.

${ }^{21}$ Ibid. L. 45-46.

${ }^{22}$ Ibid. L. 46.

${ }^{23}$ Ibid. L. 46-47.

${ }^{24}$ Ibid. L. 60.
} 
events in the former Yugoslavia and, first of all, in Kosovo. Turkish officials repeatedly stated that in the event of a complication of the situation in Kosovo or Sandžak, the positions of Turkey and Albania would be the same. Turkey also supported Albania's political line to ensure the rights of the Albanians in Macedonia. Turkey and Albania endorsed the UN sanctions against Yugoslavia and believed that Kosovo should be declared a demilitarized zone, with UN troops there to prevent the conflict from spreading. Primarily the strategic objectives of its policy, as well as ethnic and religious factors and trade and economic interests, determined such a position by Turkey. ${ }^{25}$

By insisting on restoring the rights of all ethnic groups in Kosovo, Ankara avoided any unwanted comparisons with the Kurds. To reject any parallel with the situation in the southeast of Anatolia, they put forward two kinds of arguments: (1) the repression in Kosovo was on such a large scale that no comparison was possible. President Demirel even referred to the repression as "genocide"; (2) the nature of the conflict was completely different. "They call them a minority in Kosovo, but we do not have minorities in Turkey", Demirel said. ${ }^{26}$

In 1999, Turkey continued its diplomatic activity on the Kosovo issue. On January 17, 1999, Turkish Foreign Minister I. Cem sent a letter to the UN Secretary General, the NATO Secretary General, and the OSCE Chairman-inOffice on the need immediately to convene meetings of the relevant bodies of these organizations pertaining to the mass murder of ethnic Albanians in the Kosovo town of Daniel Račak. On 22 January 1999, the Turkish Navy frigate Muavenet sailed from the Göljük naval base to the Adriatic Sea to participate in possible NATO operations in the Serbian province of Kosovo. ${ }^{27}$ On January 27, 1999, I. Cem sent to his colleagues in the United States, Russia, France, Great Britain, Germany, and Italy a message on the Kosovo issue. ${ }^{28} \mathrm{He}$ also took part at the meeting of the Foreign Ministers of Southeastern Europe on the situation in Kosovo, in Bucharest on 19 March 1999. ${ }^{29}$

In addition to diplomatic activities, Turkey undertook humanitarian actions. On April 4, 1999, Turkey started providing humanitarian aid to refugees from the Serbian province of Kosovo. Ankara declared its readiness to accept and host on its territory up to 20,000 Kosovo refugees. ${ }^{30}$ This has been a permanent component of Turkey's policy toward the Turkish and Muslim communities in the region. According to the UNHCR, at the end of May 1999, there were 16.2 thousand Kosovo refugees in Turkey. ${ }^{31}$ All of these Albanians returned to Kosovo in the summer of 1999. The Turkish Red Crescent has also set up two tent camps for refugees in Macedonia (Bojana) and Albania (Elbasan).

\footnotetext{
${ }^{25}$ Boris Pochverija, "Balkany vo vneshnej politike Turcii", u: Balkany: mezhdu proshlym i budushhim. (Izdatel'stvo «Aprel' - 85». M.: 1995), 177.

${ }^{26}$ S. Gangloff, "Turkish policy toward the conflict in Kosovo...", 111.

${ }^{27}$ AVP RF. F. 194. Op. 79. P. 244. D. 7. L. 3.

${ }^{28}$ Ibid. L. 4.

${ }^{29}$ Ibid. L. 14.

${ }^{30}$ AVP RF. F. 194. Op. 79. P. 244. D. 7. L. 17.

${ }^{31}$ Ibid. F. 157. Op. 26. P. 55. D. 4. L. 16.
} 


\section{Turkey's Involvement in the Bombing of Yugoslavia}

The success of the Serbian Army in Kosovo in the summer of 1998 predetermined the intervention of NATO, which demanded a stop to the operations of the Serbian forces under the threat of bombing Belgrade. In March of 1999, negotiations began in Rambouillet, France, which did not yield results and NATO started a bombing campaign against the FRY on 24 March 1999. The Alliance put forward five conditions, including the unconditional withdrawal of the Serbian military and paramilitary units, the return of refugees, the deployment of NATO peacekeeping forces, and the establishment of a Western protectorate. ${ }^{32}$

Robert Fisk, the Middle East correspondent for the British daily The Independent, made the following comment on the "unreasonable demand for NATO troops to have free movement throughout all of Serbia": "It was a demand no sovereign country... would accept, and thus amounted to a declaration of war. NATO troops would have been occupying the entire Yugoslav Republic, from Novi Sad and Belgrade down to Montenegro. It was no surprise that the Serbs turned this down". ${ }^{33}$

The next day, Turkey expressed its full support for the NATO air campaign. ${ }^{34}$ On April 5, 1999, President Demirel sent a message to US President Clinton stressing the need to bring NATO's operation to a victorious end, and on April 8 declared Turkey's readiness to support NATO's possible decision to conduct a land operation in the Yugoslav province of Kosovo. ${ }^{35}$ On 11 May 1999, the Turkish Council of Ministers granted the Turkish General Staff the authority to prepare its air bases in Balikesir and Bandirma to receive NATO planes participating in the aggression against Yugoslavia. Prime Minister B. Ecevit said on May 12 that Turkey would fulfill its allied obligations to NATO in the case of the use of Turkish air force bases for the bombing of Yugoslavia. ${ }^{36}$

To the surprise of many, Turkey took part in the bombing of Yugoslavia. The Turkish contingent arrived on 18 May 1999 at the port of Durres to join the NATO humanitarian forces in Albania. ${ }^{37}$ This represented a marked change in Turkey's policy compared to its response to the conflict in BosniaHerzegovina, and its behavior since the beginning of the Kosovo crisis in the spring of 1998. Most analysts did not expect Turkey to do this.

Turkey made its military air facilities available to NATO for the alliance's attacks against Yugoslavia and also supplied its F-16 fighter jets as escorts for the bomber squadrons. Of these, 11 F-16 TAI were stationed at the NATO base in Aviano, Italy, while 7 were based in Ankara. The Turkish planes

\footnotetext{
${ }^{32}$ Ibid. L. 2.

${ }^{33}$ Ibid. F. 167. Op. 67. P. 105. D. 4. L. 4.

${ }^{34}$ Ibid. F. 194. Op. 79. P. 244. D. 7. L. 15.

${ }^{35}$ Ibid. L. 17.

${ }^{36}$ AVP RF. F. 194. Op. 79. P. 244. D. 7. L. 22

${ }^{37}$ Ibid. F. 157. Op. 26. P. 55. D. 4. L. 10.
} 
had previously patrolled the airspace of the Balkans, providing protection for attacking aircraft. During this allied air campaign, the TAI F-16 set a world record by patrolling for 9 hours and 22 minutes. Typically, military air patrols last from 3 to 4 hours. ${ }^{38}$

On March 29, 2000, one year after the NATO airstrikes against Yugoslavia, The Independent's Middle East correspondent Robert Fisk and Austrian writer Peter Handke lambasted both the motives and the outcome of the war at the start of a two-day conference organized by the Athens Journalist Union, as reported by the Athens News on March 30, 2000. Fisk, who covered NATO's campaign in both Belgrade and Kosovo in 1999, compared the effects on the civilian and military populations with the use of carcinogenic depleted uranium (DU) - reinforced projectiles in both the 1991 Gulf War and the Kosovo campaign. "The British Ministry of Defense acknowledges only a very low radiation hazard from this weapon... Thousands of Iraqis think differently about the British estimate. An American military document states that 'significant concentrations of DU oxide dust could be expelled from the fire in the event of an explosion after an appreciable amount of DU has been oxidized," Fisk said. He pointed out NATO's reluctant admission that depleted uranium was indeed used in the Kosovo campaign and its dubious claims about its effects. "After all we had found out in Iraq, the Americans were using depleted uranium ammunition again. Their A-10 aircraft were using it across Kosovo," Fisk said. He also challenged NATO's humanitarian motive and suggested the alliance was not bombing to get refugees back into their homes. "No television station pointed out that most of those people were still in their homes when NATO launched its airstrikes" he said criticizing the Western mass media. For his part, Handke also slammed the Kosovo campaign. "Behind the moral mask, NATO is even worse than gangsters," he said. He went on to blast the western media as being prisoners of their own lies and expressed pessimism about the future. ${ }^{39}$

In the conference organized by the Athens Journalist Union, Philip Knightley, a correspondent of The Sunday Times, pointed out that the "Western public did not know at first that NATO was lying when it said it did not deliberately attack civilian targets...". He quoted British war historian Alistair Home as saying: "Kosovo turned out to be the most secret campaign in living memory". John Pilger suggested, "in another age, NATO expansion into Eastern Europe, the Balkans and the Caucasus would be called imperialism... but the word is banned". ${ }^{40}$

NATO Secretary General J. Robertson, in his March 21, 2000 message to UN Secretary General C. Annan, acknowledged the fact that during the operation against FRY NATO jets used warheads containing depleted uranium. Aircraft released a total of 31 thousand of these shells. Referring to the data of the

\footnotetext{
38 Justus Leicht, "Why is Turkey supporting the war against Serbia?" 26 May 1999 // World Socialist Web Site https://www.wsws.org/en/articles/1999/05/turk-m26.html (accessed: March 4, 2019).

${ }^{39}$ AVP RF. F. 167. Op. 67. P. 105. D. 4. L. 4.

${ }^{40}$ Ibid. L. 6.
} 
international group "Focus", the Greek newspaper Kathimerini, in an article dated January 9, 2001, reported that 800 tons of hydrochloric acid, 2,500 tons of ammonia, 3,000 tons of caustic soda, $200 \mathrm{~kg}$ of metallic mercury, 30 tons of liquid chlorine, and 1,400 tons of substances containing chloroethylene had fallen into the Danube River. ${ }^{41}$

NATO's bombing of Yugoslavia in 1999 grossly violated the provisions of the UN Charter. Based on Article 39 of the UN Charter, only the UN Security Council "shall determine the existence of any threat to peace, breach of peace, or act of aggression, and shall make recommendations or decide what measures shall be taken in accordance with Articles 41 and 42, to maintain or restore international peace and security". Article 41 provides "measures not involving the use of armed force". According to Article 42, "should the Security Council decide that measures provided for in Article 41 would be inadequate or have proved to be inadequate, it may take such action by air, sea, or land forces as may be necessary to maintain or restore international peace and security".

The Security Council did not determine the existence of any threat to peace in Yugoslavia and accordingly did not adopt a resolution on the use of force against Yugoslavia. Therefore, the use of force by NATO without the authorization of the UN Security Council constituted an act of aggression against a sovereign and independent country. Resolution 3314, adopted by the UN General Assembly on December 14, 1974, entitled "Definition of Aggression" unequivocally states: "Any of the following acts... shall ... qualify as an act of aggression: ... Bombardment by the armed forces of a state against the territory of another State" (Article 3, paragraph b); "no consideration of whatever nature, whether political, economic, military or otherwise, may serve as justification for aggression" (Article 5, paragraph 1); "a war of aggression is a crime against international peace; aggression gives rise to international responsibility" (Article 5, paragraph 2); "no territorial acquisition or special advantage resulting from aggression is or shall be recognized as lawful" (Article 5 , paragraph 3$).{ }^{42}$

Apart from UN Security Council authorization, the use of force is considered to be legal only for the implementation of "the inherent right of individual or collective self-defense if an armed attack occurs against a member of the United Nations" as provided for in Article 51 of the UN Charter. No NATO member was subjected to any armed attack. Consequently, NATO committed an act of collective aggression. Yugoslavia used its right to self-defense, in accordance with Article 51 of the UN Charter. The NATO bombing of Yugoslavia was the first blatant and impudent act of violating international law since the end of the Cold War.

\footnotetext{
${ }^{41}$ Ibid. Op. 68. P. 108. D. 4. L. 8.

42 Resolution 3314 "Definition of Aggression", 14 December 1974 // The United Nations. General Assembly. Previous Sessions. URL: https://undocs.org/en/A/RES/3314(XXIX) (date accessed: 29.09.2019).
} 


\section{Reasons for Participation in the Bombing}

After the bombing, the Turkish leaders tried to justify their participation in the air strikes. President Demirel mentioned the "duty to save our Kosovar brethren", former Prime Minister Ecevit stated that "Kosovars are our brothers and the legacy of our history," Foreign Minister Cem pointed to the "500 years' experience in Kosovo". ${ }^{43}$

This discourse appeared in 1998 after the refusal of the EU in December 1997 to consider the Turkish candidacy. ${ }^{44}$ The EU actually closed the door to Turkey, which caused this country's furious reaction. NATO remained the only Western entity where Turkey enjoyed full rights. In these circumstances, Turkey considered it necessary to strengthen its position in the Alliance. Turkey took part in the bombing a few weeks after the Washington summit of April 2324,1999 , at which it had to fight hard against the proposal to launch a European defense and security identity, which could have led to Turkey's isolation. Turkey tried its best to avoid it. After the EU's rejection and the above-mentioned initiative, which was reflected in the decisions of the Washington summit, Turkey considered participation in NATO bombing as the only way to confirm its belonging to the Western community. Just weeks after the Washington summit, Turkey took part in the NATO operation.

Interestingly enough, all this coincided with the election campaign to the legislative bodies, held on April 18, 1999. All parties and candidates were in competition in their adherence to the Balkan brothers. A few days before the elections, Prime Minister Ecevit visited the Kurklareli camp, where Albanian refugees were settled. In addition, the fear that the Islamist party Fazilet would gain more votes incited the "secular" politicians to compete with it. Tansu Çiller, the leader of the conservative party Doğru Yol Partisi, criticized the government for its "apathy toward Kosovo". ${ }^{5}$

The following is an explanation of Turkey's broad interests in the region, offered by Turkish Ambassador Sukru Elekdag: "Turkey is deeply concerned with the security and stability of the Balkans because of her geo-strategic interests, and has to follow an active policy toward this region. The Balkan Peninsula is an advance defense zone for Thrace, the Turkish Straits and Istanbul. Therefore, Ankara's sensitivity toward the conflicts and geopolitical changes in the region has an understandable source... Turkey, in a key location and is a bridge between three continents; it has a unique geo-political identity within the region, controlling all the communication lines via air, land or sea. With its location, Turkey is a focus of power not only for the Balkans, but also for the Caucasus-Central Asia corridor and the Middle East".

\footnotetext{
${ }^{43}$ S. Ganfloff, "Turkish policy toward the conflict in Kosovo...”, 113.

${ }^{44}$ Sylvie Gangloff, "The Impact of the Ottoman Legacy on Turkish Policy in the Balkans (19911999)", SERA, (November 2005), 16.

${ }^{45}$ S. Gangloff, "The Impact of Ottoman Legacy...”, 17.
} 
Based on the above-mentioned conclusion and referring to President Demirel's statement, Justus Leicht argued that Turkey was therefore deliberately using the war against Yugoslavia to secure its domination in the Balkans in opposition to Greece. "What can be the reasons or expectations which have changed our policy?" President Demirel answered this question saying "we cannot act like Greece". This statement, according to Leicht, reveals that the main consideration was to place Turkey above Greece, which was standing by Serbia. The President went on to say that, loyalty was one of the main factors in deciding Turkish policy. He added that Turkey was a first-class member of NATO and to drop to the position of a second- or third-class member would go against Turkey's interests. Turkey is among the top five NATO countries, and she should not lose this position. This means that the decision was taken to consolidate Turkey's position in the West and strengthen its pro-Western policy. $^{46}$

\section{Turkey's Participation in the Post-War Settlement in Kosovo}

After the end of the bombing in June 1999, Turkey took part in the international peacekeeping forces deployed in Kosovo. The transfer of the Turkish peacekeeping battalion to Kosovo began on 30 June 1999. ${ }^{47}$ An advance military group from the Turkish peacekeeping battalion arrived in Kosovo on 4 July 1999. ${ }^{48}$ The Turkish soldiers were stationed in the South-West of the region, in the German sector, where the Turkish community mainly lived.

Turkish officials began visiting the region. The first such a visit was made by I. Cem on July 17-18, 1999. He visited the headquarters of the Turkish peacekeeping battalion, met with M. Jackson, the head of NATO peacekeeping forces in Kosovo, H. Thaçi, the leader of the political wing of the socalled Kosovo Liberation Army, and B. Bukoshi, the head of the so-called Kosovo Government. ${ }^{49}$ Finally, the Turkish coordination offices were opened in Priština and Prizren in July of 1999 during Cem's visit. Officially, they were tasked with coordinating the distribution of Turkish humanitarian aid in the province. President Demirel visited Kosovo on 17 October 1999. He was accompanied by Defense Minister S. Çakmakoğlu and Chief of Staff $H$. Kıvrıkoğlu. ${ }^{50}$

After the establishment of the UN Mission in Kosovo (UNMIK) in June 1999, the Kosovo Turks were represented through the Committee of the Transnational Council of Kosovo headed by the UN Special Representative and Head of the UN Interim Administration Mission in Kosovo Bernard Kouchner. However, many Turks did not feel at home in Kosovo, especially after the war of

\footnotetext{
${ }^{46}$ J. Leicht, op. cit.

${ }^{47}$ AVP RF. F. 194. Op. 79. P. 244. D. 7. L. 28.

48 Ibid. L. 30.

49 Ibid. L. 31.

${ }^{50}$ Ibid. L. 44.
} 
1999. It is estimated that about 20,000 people arrived in Turkey during the flood of refugees from Kosovo. Most of the Turks who returned to their homeland in Kosovo faced hostility toward all non-Albanians. Moreover, since then they have had to fight not only against the regular accusations of Albanians that they cooperated with the Serbian authorities, but also against UNMIK's anti-Turkish practices. In particular, the UN mission in Kosovo did not recognize Turkish as an official language, printing the ballots in English (?!), Albanian, and Serbian, but not in Turkish. ${ }^{51}$

Therefore, one of the constant directions of Turkey's policy toward Kosovo was the insistence on the participation of the Turkish minority in the peace talks. The Serbs fully supported this request, which allowed them to disrupt Albanian unity in Kosovo. In his letter to Bernard Kouchner, the UN Special Representative and Head of the UN Interim Administration Mission in Kosovo, Turkish Foreign Minister Cem, pleaded for the recognition of Turkish as an official language and even threatened to withdraw Turkish support to Kosovo if "the political and cultural rights of the Turkish minority were not protected". ${ }^{2}$

The international administration in Kosovo gradually granted rights to the Turkish minority. B. Kouchner visited Ankara on August 1, 2000. At a meeting with Foreign Minister I. Cem he discussed the issue of the Turkish community of Kosovo. ${ }^{53}$ Two months later, on 15 September Turkish was recognized as an official language in the province. Kouchner promised the Kosovo Turkish community rights that were granted by the 1974 Yugoslav Constitution, that the UNMIK regulations would be issued also in Turkish in areas inhabited by Turkish communities, and that ID cards would be issued in Turkish. The International Peacekeeping Force (KFOR) had already started to broadcast in Turkish in December 1999 and a Turkish weekly, Yeni Dbnem, has been in print since then. ${ }^{54}$

Progress has definitely been made with regard to the demands of the Turks. But problems continued to arise regularly. For example, during the 2000 municipal elections, the Turkish community decided to boycott the OSCE registration process because the forms were not in their native language. Nevertheless, an agreement was finally reached with the Kosovo Turkish leaders and they registered for the general elections in November of 2001. ${ }^{55}$

The Turkish media though unanimously supported the NATO operation, ${ }^{56}$ but at the same time with irritation noted: "Turkey again has remained out of business in the post-war settlement in the Balkans". Some criticism was voiced against the Turkish Foreign Ministry, "which failed to show activity and

\footnotetext{
${ }^{51}$ Ş. Kut, op. cit.

${ }^{52}$ S. Ganfloff, "Turkish policy toward the conflict in Kosovo...", 119.

${ }^{53}$ AVP, RF. F. 194. Op. 80. P. 248. D. 9. L. 96.

${ }^{54}$ S. Ganfloff, "Turkish policy toward the conflict in Kosovo...", 120-121.

${ }^{55}$ Report on the Secretary-General on the United Nations Interim Administration Mission in Kosovo, 7 June $2001 / /$ United Nations. Security Council. S/2001/565. URL: https://unmik. unmissions.org/sites/default/files/s-2001-565.pdf (accessed: 15. 3. 2019).

${ }^{56}$ AVP RF. F. 194. Op. 79. P. 244. D. 7. L. 68.
} 
perseverance to ensure for Turkey a dignified place in the division of spheres of influence in Kosovo". ${ }^{57}$

In Kosovo, politics and crime have become entangled to an unprecedented degree, as Stavros Tzimas argued in an article in Kathimerini's January 8, 2001 edition. He wrote about Gani Thaçi, the brother of "Prime Minister" Hashim Thaçi, who was arrested by KFOR in 2000 in Pristina after being caught smuggling weapons and a million Deutsch marks in his luxury car. $\mathrm{H}$. Thaçi got him out of prison within a few hours and since then Gani has had a successful career smuggling petroleum, mostly through Skopje. Tzimas, referring to a "smuggler's paradise", concludes: "The International Community... tolerate it because of more general geostrategic expediencies". ${ }^{58}$

Turkey believes that the international presence, especially in Kosovo and Bosnia-Herzegovina, is important and necessary both for strengthening the state institutions in these countries and for regional stability. Turkey, therefore, contributed to the IFOR in Bosnia-Herzegovina and the SFOR in Kosovo and Operation Essential Harvest, Amber Fox, and Allied Harmony in Macedonia. Turkey has also made a comprehensive contribution to EU-led peacekeeping operations and missions, such as the ALTEA European Force and the EU Police Mission in Bosnia-Herzegovina and the EU Rule of Law Mission in Kosovo. ${ }^{59}$

Turkey supported the preservation of the territorial integrity of Yugoslavia and demanded the extension of Kosovo's autonomy with maximum rights for all ethnic groups, including the Turkish community. In early 2001, political consultations were initiated with a view to renewing ties with the FRY. Radojko Bogojević, the assistant minister of foreign affairs of Yugoslavia arrived in Ankara on February 12, 2001 where he met with Yiğit Alpogan, the deputy undersecretary in the Turkish Foreign Ministry. They discussed the situation in the Balkans and decided to hold political consultations between Turkey and the FRY. ${ }^{60}$ Turkish Foreign Minister Cem paid an official visit to Belgrade on 2-3 March 2001. He met with Yugoslav President Vojislav Koštunica, Prime Minister Zoran Djindjić, and Foreign Minister Goran Svilanović. ${ }^{61}$ This, the first official visit by a Turkish foreign minister to Belgrade since 1992, is considered to be a turning point in bilateral relations.

\footnotetext{
${ }^{57}$ Ibid. L. 72.

${ }^{58}$ Ibid. F. 167. Op. 68. P. 108. D. 4. L. 4, 7.

59 Turkey's International Security Initiatives and Contributions to NATO and EU Operations // Republic of Turkey. Ministry of Foreign Affairs. Foreign Policy. Main Issues. Turkey's Security NATO. More Information about Turkey's Security NATO. URL: http://www.mfa.gov.tr/iv_european-security-and-defence-identity_policy-_esdi_p_en.mfa (date accessed: 2. 6. 2018).

${ }^{60}$ AVP RF. F. 194. Op. 81. P. 253. D. 10. L. 82.

${ }^{61}$ Ibid. L. 88.
} 


\section{Conclusions}

The Balkans is important for Turkey for geopolitical, geostrategic, and cultural-historical reason. Turkey has become active in the Balkans due to the war in Bosnia-Herzegovina. Turkey verbally supported NATO's military operations against the Serbs, but did not take part in them.

The conflict between the Serbs and Albanians in Kosovo in 1998 did not cause the same concern and the same loud reaction as the conflict in BosniaHerzegovina. Turkish officials condemned the violence, called for the protection of the rights of all minorities in the province, and proposed diplomatic measures. They have been extremely cautious in their public statements about the responsibilities of the parties in the conflict and about military actions. Turkey has continued to pursue a careful and restrained policy toward the FRY.

Even the Turkish and Muslim communities in the Balkans, and the Turkish citizens of Balkan origin, were not initially factors influencing Turkey's policy. In the Balkans, the web of relationships was very complicated. Relations between the Turks and the other Muslims, namely Bosnians and Albanians differed. Relations between the Turks and the Albanians in Kosovo were very complex. Kosovo's Turkish minority feared reprisals from the Albanian majority, which was particularly chauvinistic. Here the interests of the Turks and the Serbs coincided. In general, the Turks were concerned about their long-term survival in Kosovo as an ethnic group.

The Turkish minority, as well as other minorities in Kosovo, became the subject of intense political interest only after the bombing had begun, when the political leadership considered it appropriate for their political agenda. The EU's refusal to consider Turkey's candidacy; the initiative to create a European defense and security identity that might have isolated Turkey; the desire to outflank Greece in the Balkans; the legislative elections in April of 1999, were among the important factors. Domestically, the political parties sought to win elections and repressions against the Muslim Albanians and concern for their Turkish brothers in Kosovo provided a convenient opportunity for campaigning. In foreign policy, compared with Greece, also a Balkan country, which did not participate in the bombing, it was necessary to pursue a more active policy in the Balkans in order to outmaneuver it. It was especially important to do this after the EU's rejection of Turkey's candidacy. NATO remained the only Western structure where Turkey was a full participant. The preservation of Turkey's status as a first-class member of the Alliance was a concern. Therefore, Turkey took a decision to participate in the Alliance's campaign.

It is not surprising that Turkey's policy in the Balkans in the context of the Yugoslav crisis was to follow the policy of its Euro-Atlantic allies. It pursued its interests mainly within and through NATO, which generally provided the infrastructure. Within the West, however, there was no unity. Europe, represented by Germany and France, supported Slovenia and Croatia against the 
Serbs; the Americans were on the side of the Bosnians and the Albanians against Serbia. Turkey, itself a Balkan country, had kindred communities mainly in Yugoslavia, within which their interests were just being served. Therefore, Turkey tried to maintain appropriate relations with the FRY. Relations with Yugoslavia served as a balance between the latter and Greece. The fact that Turkey was able to resume relations with the FRY in 2000 and develop them further suggests that participation in the bombing was an undesirable step, but done reluctantly and under pressure. Participation in the bombing did not meet the fundamental strategic interests of Turkey. Perhaps for the first time, it was in Yugoslavia that Turkey's national and regional interests came into conflict with its membership in NATO and in the Western camp as a whole. Here was what we would call "Turkey's Balkan dilemma". Subsequent events in the Middle East have only confirmed this. 


\section{REFERENCES}

- Eralp, Doğa Ulaş. "Turkey and Bosnia-Herzegovina: A Future Reflecting on the Past". SETA. Policy Brief. no. 46, (August 2010), 3-9.

- Gangloff, Sylvie. "Turkish Policy toward the Conflict in Kosovo: The Preeminence of National Political Interest". Balkanogie, vol. 8, no. 1, (2004), $105-122$.

- Gangloff, Sylvie. "The Impact of Ottoman Legacy on Turkish Policy in the Balkans (1991-1999)". CERI, (November 2005), 1-20.

- Karpat, Kemal. "Turkish Foreign Policy: Some Introductory Remarks". In: Turkish Foreign Policy: Recent Developments. Kemal H. Karpat (eds.), 1-18. Madison: Wisconsin, 1996.

- Kut, Şule. "Turks of Kosovo: What to Expect?" Perceptions, vol. V, no. 3, (September-November 2000), 1-7.

- Leicht, Justus. "Why is Turkey supporting the war against Serbia?" 26 May 1999 in World Socialist Web Site https://www.wsws.org/en/articles/1999/05/ turk-m26.html (accessed: March 4, 2019).

- Marija, Mitrovic. 2014: Turkish Foreign Policy toward the Balkans: The influence of traditional determinants on Davutoğlu's conception of Turkey - Balkan relations. GeT MA Working Paper No. 10. Department of Social Sciences, Humboldt-Universität zu Berlin. [online] Homepage: Edoc Server HumboldtUniversität zu Berlin. URL: http://edoc.hu-berlin.de/series/getmaseries

- NATO Demolishes Yugoslavia. The 70 years of NATO: form Wat to War, April 26, 2019 in Global Research. URL: https://www.globalresearch.ca/natodemolishes-yugoslav-state/5675712

- Paniev G. E. "Sovremennaja politika Turcii na Balkanah" [Turkey's Current Policy in the Balkans]. Vestnik Pjatigorskogo gosudarstvennogo lingvisticheskogo universiteta. Molodezhnoe prilozhenie. № 1. Pjatigorsk, (2002).

- Pochverija, Boris. "Balkany vo vneshnej politike Turcii" [The Balkans in Turkey's Foreign Policy]. In: Balkany: mezhdu proshlym i budushhim. Izdatel'stvo «Aprel' - 85». M.: 1995.

- Remiddi, Adriano. "Tureckoe vtorzhenie na Zapadnye Balkany: perspektiva evro-atlanticheskogo primirenija" [Turkish Invasion into the Western Balkans: Prospect of Euro-Atlantic Reconciliation]. In: Jugo-Vostochnaja Evropa: mezhdu proshlym i budushhim. Doklady Instituta Evropy. № 290. (M.: 2013. Institut Evropy RAN: Rus. Souvenir).

- Uzgel, Ilhan. "Kosovo; Politics of Nationalism and the Question of International Intervention". Turkish Review of Balkan Studies, 4, (1998-1999). 
ILGAR MAMEDOV, Candidate of Historical Sciences, Senior Research Fellow Institute of Slavic Studies, Russian Academy of Sciences

Moscow, Russian Federation

ilgarmm@yandex.com

\section{THE BALKAN POLICY OF TURKEY IN CONNECTION WITH THE KOSOVO CRISIS IN 1998-1999}

\section{Summary}

The Balkans and Turkey retained close links. Turks and Muslims reside in the Balkans and many Turks are of Balkan origin. With the start of the Kosovo crisis in 1998 the Turkish Albanians wanted to lobby for their brethren. Turkey, however, was very cautious, pursuing a policy of noninterference and calling for diplomacy. There were several factors at play. The local Turks were under oppression by the Kosovo Albanians. Kosovo was a part of Yugoslavia, a country where Turks were treated fairly well and with which Turkey had good relations, considering it as a balance against Greece. In the course of 19981999, certain developments affected Turkish policy. The EU's refusal to consider Turkey's candidacy in 1998, the European defense and security identity of 1999 that might have isolated Turkey in the Western community, the wish to outmaneuver Greece, which did not participate in the NATO operations, the 1999 local elections, which presented an opportunity to express support for kin communities in Kosovo, were the factors which forced Turkey to join the NATO air strikes against Yugoslavia, which turned out to be the only Western club Turkey was a part of and it desired to reinforce its status there. Participation in the air campaign was a reluctant step, done under compulsion, and did not fulfill the basic interests of Turkey. Turkey's regional interests in the Balkans were in contradiction with its membership in NATO and the interests of the Western camp. That was, as we termed it, "Turkey's Balkan dilemma".

KEYWORDS: Aggression, Albania, Balkans, Turkey's Balkan Dilemma, Bombing, Kosovo, NATO, Turkey, Yugoslavia 